\title{
KUALITAS PELAYANAN DAN ALTERNATIF MODEL PELAYANAN \\ PENYULUHAN PERTANIAN \\ DI ERA OTONOMI DAERAH
}

\author{
Faria Ruhana \\ Dosen di Institut Pemerintahan Dalam Negeri, \\ Jl. Raya Bandung-Sumedang Km 20 Jatinangor, Sumedang \\ e-mail : nurhana07@yahoo.co.id
}

\begin{abstract}
ABSTRAK. Penelitian ini dilakukan dengan metode survey. Tujuan dari penelitian adalah untuk mengetahui kualitas pelayanan penyuluhan pertanian kepada petani di Kabupaten Garut. Di samping itu untuk menganalisis dan memberikan alternatif model penyuluhan pertanian. Dari penelitian ini diperoleh temuan penting bahwa setelah diberlakukan otonomi daerah jumlah, kualitas dan kompetensi penyuluh pertanian justru menurun. Hal ini mengakibatkan kualitas pelayanan yang diberikan kepada petani menjadi menurun pula. Sedangkan dari pengkategorian skor pada penerapan teori Zeithaml, et. al. (1990) menunjukkan bahwa dimensi assurance mendapatkan penilaian paling rendah dari responden. Sehingga perubahan kualitas pelayanan sebaiknya dimulai dengan memperbaiki indikator pembentuk dimensi ini. Berikutnya perubahan dilakukan bertahap atau paralel pada dimensi reliability, tangible, responsiveness dan empathy. Model pengembangan yang dapat diberikan yaitu menyediakan fasilitas sistem informasi disertai pelatihan yang intensif guna meningkatkan kinerja penyuluh pertanian, sehingga akhirnya meningkatkan kualitas pelayanan yang diberikan.
\end{abstract}

Kata kunci : kualitas pelayanan, penyuluhan pertanian, otonomi daerah

\section{QUALITY SERVICES AND ALTERNATIVE MODEL OF AGRICULTURAL COUNSELLING SERVICE IN THE ERA OF REGIONAL AUTONOMY}

\begin{abstract}
This researchs with method of survey with the purpose to determine the quality of agriculture counseling services to the farmers, was conducted in Garut District, in addition to analyzing and providing an alternative model of agricultural counseling. This research obtained important findings that the effect of regional autonomy, the quality and competence of agricultural counseling workers is decreasing. This resulted in the quality of services provided to farmers to be declining too. While the scores on the application of categorization theory Zeithaml, et. al. (1990) shows that the dimension of assurance of getting the lowest ratings from respondents. So that changes in service quality should start with improving the indicators of this dimension formation. The next change is
\end{abstract}


gradual or parallel to the dimensions of reliability, tangible, responsiveness, and empathy. Development model given provides information systems with intensive training in order to improve the performance of agricultural counselor, eventually improve the quality of services provided.

Keywords : service quality, counselling of agriculture, regional autonomy

\section{PENDAHULUAN}

Penyuluhan pertanian sebagai bagian integral pembangunan pertanian merupakan faktor penting yang menentukan keberhasilan pembangunan pertanian secara keseluruhan. Pengalaman menunjukkan bahwa penyuluhan pertanian di Indonesia telah memberikan sumbangan yang signifikan pada pencapaian program pembangunan pertanian. Hal ini terbukti pada pencapaian swasembada beras pada tahun 1984 melalui program Bimbingan Masal (Bimas).

Pada era reformasi dan otonomi daerah seperti saat ini, pendekatan yang pernah dilakukan, yaitu dengan dipaksa, terpaksa dan biasa tentu sudah tidak relevan lagi diterapkan. Masyarakat dalam hal ini petani dan keluarganya sudah menginginkan untuk dapat menjalankan usaha taninya sesuai dengan keinginannya sendiri berdasarkan pilihan-pilihan yang mereka anggap tepat dan lebih menguntungkan. Masalah yang timbul kemudian adalah bahwa otonomi daerah ternyata lebih mengindikasikan ketidakberpihakannya pada sektor pertanian. Jika Pendapatan Asli Daerah (PAD) menjadi salah satu tolok ukur keberhasilan kinerja daerah, maka sektor pertanian memang bukan pilihan yang menarik karena kurang mendatangkan PAD yang besar di banding sektor lain. Dengan demikian, maka pembangunan pertanian di daerah menjadi tersendat karena tidak menjadi prioritas. Hal ini dirasakan pula oleh para penyuluh pertanian di KPSDMP-KP Kabupaten Garut sehingga berdampak pada penurunan kualitas pelayanan yang diberikan kepada petani.

Kualitas pelayanan penyuluhan yang baik menjadi salah satu penentu keberhasilan pembangunan pertanian. Menurut Zeithaml, et. al(1990:26), kualitas pelayanan ditentukan oleh lima dimensi, yaitu tangible, reliability, responsiveness, assurance dan empathy. Berdasarkan fenomena dan teori Zeithaml, et. al. di atas maka rumusan permasalahan penelitian ini adalah: 1) Apa saja temuan penting dari fakta pelayanan penyuluhan pertanian di Kabupaten Garut pasca otonomi daerah? 2) Bagaimana penerapan teori Zeithaml, et. al. (1990) tentang lima dimensi (tangible, reliability, responsiveness, assurance dan empathy) pada kualitas pelayanan penyuluhan pertanian di Kabupaten Garut? 3) Bagaimana alternatif model pelayanan penyuluhan pertanian di Kabupaten Garut?

Salah satu tugas pokok pemerintah yang terpenting adalah memberikan pelayanan kepada masyarakat, karena itu organisasi pemerintah sering disebut sebagai 'pelayan masyarakat' (public servant). Pelayanan publik yang harus diberikan oleh pemerintah seperti yang dikemukakan oleh Mahmudi (2005:229) dapat diklasifikasikan ke dalam dua kategori utama, yaitu pelayanan kebutuhan 
dasar (meliputi kesehatan, pendidikan dasar dan bahan kebutuhan pokok masyarakat ) dan pelayanan umum (terdiri dari pelayanan administratif, pelayanan barang, pelayanan jasa).

Berdasarkan Keputusan Menteri Pendayagunaan Aparatur Negara Nomor 63/KEP/M.PAN/7/2004 tentang Pedoman Umum Penyelenggaraan Pelayanan Publik bahwa dalam memberikan pelayanan publik, instansi penyedia pelayanan publik harus memperhatikan asas pelayanan publik, yaitu transparansi, akuntabilitas, kondisional, partisipatif, tidak diskriminatif (kesamaan hak) serta keseimbangan hak dan kewajiban.

Selanjutnya, berdasarkan Keputusan Menteri Pendayagunaan Aparatur Negara Nomor 25/M.PAN/2/2004 tentang Pedoman Umum Penyusunan Indeks Kepuasan Masyarakat Unit Pelayanan Instansi Pemerintah kemudian dikembangkan menjadi 14 unsur yang "relevan, valid" dan "reliabel", sebagai unsur minimal yang harus ada untuk dasar pengukuran indeks kepuasan masyarakat adalah sebagai berikut:

1. Prosedur pelayanan, yaitu kemudahan tahapan pelayanan yang diberikan kepada masyarakat dilihat dari sisi kesederhanaan alur pelayanan;

2. Persyaratan Pelayanan, yaitu persyaratan teknis dan administratif yang diperlukan untuk mendapatkan pelayanan sesuai dengan jenis pelayanannya;

3. Kejelasan petugas pelayanan, yaitu keberadaan dan kepastian petugas yang memberikan pelayanan (nama, jabatan serta kewenangan dan tanggung jawabnya);

4. Kedisiplinan petugas pelayanan, yaitu kesungguhan petugas dalam memberikan pelayanan terutama terhadap konsistensi waktu kerja sesuai ketentuan yang berlaku;

5. Tanggung jawab petugas pelayanan, yaitu kejelasan wewenang dan tanggung jawab petugas dalam penyelenggaraan dan penyelesaian pelayanan;

6. Kemampuan petugas pelayanan, yaitu tingkat keahlian dan ketrampilan yang dimiliki petugas dalam memberikan/ menyelesaikan pelayanan kepada masyarakat;

7. Kecepatan pelayanan, yaitu target waktu pelayanan dapat diselesaikan dalam waktu yang telah ditentukan oleh unit penyelenggara pelayanan;

8. Keadilan mendapatkan pelayanan, yaitu pelaksanaan pelayanan dengan tidak membedakan golongan/status masyarakat yang dilayani;

9. Kesopanan dan keramahan petugas, yaitu sikap dan perilaku petugas dalam memberikan pelayanan kepada masyarakat secara sopan dan ramah serta saling menghargai dan menghormati;

10. Kewajaran biaya pelayanan, yaitu keterjangkauan masyarakat terhadap besarnya biaya yang ditetapkan oleh unit pelayanan;

11. Kepastian biaya pelayanan, yaitu kesesuaian antara biaya yang dibayarkan dengan biaya yang telah ditetapkan; 
12. Kepastian jadwal pelayanan, yaitu pelaksanaan waktu pelayanan, sesuai dengan ketentuan yang telah ditetapkan;

13. Kenyamanan lingkungan, yaitu kondisi sarana dan prasarana pelayanan yang bersih, rapi, dan teratur sehingga dapat memberikan rasa nyaman kepada penerima pelayanan;

14. Keamanan Pelayanan, yaitu terjaminnya tingkat keamanan lingkungan unit penyelenggara pelayanan ataupun sarana yang digunakan, sehingga masyarakat merasa tenang untuk mendapatkan pelayanan terhadap resikoresiko yang diakibatkan dari pelaksanaan pelayanan.

Peningkatan kualitas pelayanan publik sangat diperlukan dalam menjawab tuntutan publik akan prinsip better quality of life dan arus globalisasi. Untuk itu diperlukan strategi sebagaimana dikemukakan oleh De Vreye (Sugiyanti, 1999 : 28-29) yang disebut simple strategi for succes yang kemudian disebut service model, yaitu :

1. Self-esteem (harga diri):

2. Exeed expectation (memenuhi harapan)

3. Recovery (pembenahan)

4. Vision (pandangan ke depan)

5. Improve (perbaikan)

6. Care (perhatian)

7. Empower (pemberdayaan)

Menurunnya kualitas pelayanan akan membawa dampak buruk pada citra organisasi publik tersebut, karena masyarakat yang menerima pelayanan buruk tersebut akan menyampaikan kepada pihak lain dan hal ini akan membentuk pendapat umum tentang organisasi publik tersebut. Oleh karena itu untuk menjaga agar organisasi publik tetap memiliki citra baik dalam pandangan masyarakat, maka perlu dilakukan peningkatan kualitas pelayanan. Gaspersz (1997:2) menyebutkan adanya beberapa dimensi atau atribut yang harus diperhatikan dalam perbaikan kualitas layanan, yaitu:

1. Ketepatan waktu pelayanan;

2. Akurasi pelayanan, yang berkaitan dengan reliabilitas;

3. Kesopanan dan keramahan dalam memberikan pelayanan;

4. Tanggungjawab yang berkaitan dengan penerimaan pesanan, maupun penanganan keluhan;

5. Kelengkapan, menyangkut ketersediaan sarana pendukung;

6. Kemudahan dalam mendapatkan pelayanan

7. Variasi model pelayanan, berkaitan dengan inovasi;

8. Pelayanan pribadi, berkaitan dengan fleksibilitas/penanganan permintaan khusus;

9. Kenyamanan dalam memperolell pelayanan, berkaitan dengan lokasi, ruang, kemudahan, informasi; 
10. Atribut yaitu pendukung pelayanan lainnya seperti kebersihan lingkungan, AC, fasilitas ntang tunggu, fasilitas musik atau TV, dan sebagainya.

Dalam kaitannya dengan kualitas pelayanan masyarakat, Lovelock and Wirtz (1994:179) mengemukakan bahwa suatu produk bila ditambah dengan pelayanan (service) yang baik akan menghasilkan suatu kekuatan yang memberikan manfaat dan keuntungan bahkan untuk menghadapi persaingan.

Kepuasan masyarakat sebagai penerima layanan merupakan perbandingan antara layanan yang diterima (perceived service) dengan layanan yang diharapkan (expected service). Bila hasilnya mendekati satu maka masyarakat akan puas, begitu juga sebaliknya bila harganya jauh lebih kecil dari satu maka masyarakat semakin tidak puas. Salah satu produk organisasi publik adalah pelayanan publik. Seperti yang disampaikan oleh Lenvine et. al. (1990:188), maka produk pelayanan publik didalam negara demokrasi paling tidak harus memenuhi tiga indikator, yakni responsiveness, responsibility, dan accountability.

Selanjutnya, Zeithaml et. al. (1990:20), menyatakan bahwa lima dimensi dimensi SERVQUAL (Kualitas Pelayanan) sebagai berikut :

1. Tangible : appearance of physical facilities, equipment personnel and communication materials

2. Reliability : ability to perform the promised service dependably and provide prompt service

3. Responsiveness : willingness to help customers and provide prompt service

4. Assurance : knowledge and courtesy of employees and their ability to convey trust and confidence

5. Empathy : caring, individualized attention the firm provides its customers

Zeithaml et. al (1990), pada halaman pengantar dari bukunya menyatakan bahwa metode service quality tersebut dapat digunakan dan dipraktekkan untuk semua tipe pelayanan organisasi yang beroriantasi profit maupun non profit.

\section{METODE PENELITIAN}

Penelitian ini menggunakan metode survey. Menurut Singarimbun (1995: 1), penelitian survey yaitu penelitian yang mengambil sampel dari satu populasi dan menggunakan kuesioner sebagai alat pengumpulan data yang pokok. Penelitian survey pada umumnya dilakukan untuk mengambil suatu generalisasi, sebagaimana dijelaskan oleh Kline dalam Sugiyono (2004: 7) bahwa generalisasi yang dilakukan dapat lebih akurat bila menggunakan sampel yang representatif.

Populasi pada penelitian ini adalah seluruh petani yang ada di Kabupaten Garut sebanyak 65.250 orang yang terdiri dari Kelompok Tani Pemula, Kelompok Tani Lanjut, Kelompok Tani Madya dan Kelompok Tani Utama. Sampling dilakukan dengan dua tahap yaitu; Tahap pertama, teknik cluster sampling atau area sampling untuk menentukan kecamatan-kecamatan yang ditentukan sebagai lokasi 
sumber data, karena kelompok tani tersebar di seluruh Kabupaten Garut. Dari 42 kecamatan yang ada di Kabupaten Garut terpilih 10 kecamatan sebagai sampel area yaitu Kecamatan Wanaraja, Cigedug, Cikajang, Cisurupan, Tarogong Kidul, Leles, Kadungora, Kersamanah, Limbangan dan Cilawu. Tahap kedua, untuk menentukan petani yang dipilih sebagai sampel (sampel individu) digunakan teknik stratified random sampling. Ukuran sampel menggunakan rumus yang dikembangkan oleh Slovin (Umar, 2004 : 107). Pada populasi petani berjumlah 65.250 orang, pada taraf kesalahan $10 \%$ diperoleh jumlah sampel minimal sebanyak 99,9 orang (dibulatkan menjadi 100 orang). Jumlah sampel tersebut dibagi secara proporsional pada sepuluh kecamatan terpilih sesuai strata kelompok tani menggunakan alokasi proporsional (Tabel 1).

Tabel 1. Jumlah Sampel pada Populasi Petani di Kabupaten Garut

\begin{tabular}{cccc} 
No & Kelompok Tani & Jumlah & Sampel \\
\hline 1. & Kelompok Tani Utama & 850 & 2 \\
2. & Kelompok Tani Madya & 6.425 & 10 \\
3. & Kelompok Tani Lanjut & 30.675 & 47 \\
4. & Kelompok Tani Pemula & 27.300 & 41 \\
\hline & Jumlah & 65.250 & 100 \\
\hline
\end{tabular}

Pengambilan data dilakukan melalui penyebaran kuesioner kepada responden (100 orang petani). Di samping itu wawancara kepada pejabat struktural dan fungsional (penyuluh pertanian) serta petani di wilayah kerja KPSDMP-KP dan BPP di Kabupaten Garut. Skala yang digunakan dalam penelitian adalah Skala Likert. Setiap pernyataan dalam instrumen penelitian disediakan lima pilihan jawaban, jenjang masing-masing adalah 1, 2, 3, 4 dan 5. Dari hasil pengukuran ini kemudian dilakukan pengkategorian (tinggi, sedang, rendah) untuk mengetahui tanggapan responden terhadap kualitas pelayanan penyuluhan yang diberikan oleh KPSDMPKP Kabupaten Garut.

\section{TEMUAN PELAYANAN PENYULUHAN PERTANIAN DI KABUPATEN GARUT}

Berdasarkan hasil penelitian diperoleh temuan penting di mana setelah otonomi daerah faktanya justru jumlah, kualitas dan kompetensi penyuluh pertanian menjadi menurun sehingga kualitas pelayanan yang diberikan oleh KPSDMP-KP Kabupaten Garut kepada petani menjadi menurun pula.

Model pengembangan dalam rangka meningkatkan kualitas pelayanan penyuluhan pertanian diarahkan dengan memberikan fasilitas sistem informasi disertai pelatihan yang intensif untuk meningkatkan kinerja penyuluh pertanian sehingga pada akhirnya akan meningkatkan kualitas pelayanan yang diberikan. Alur pemikiran dari model pengembangan pelayanan penyuluhan pertanian 
berangkat dari struktur organisasi yang ada di KPSDMP-KP Kabupaten Garut adalah sebagai berikut :

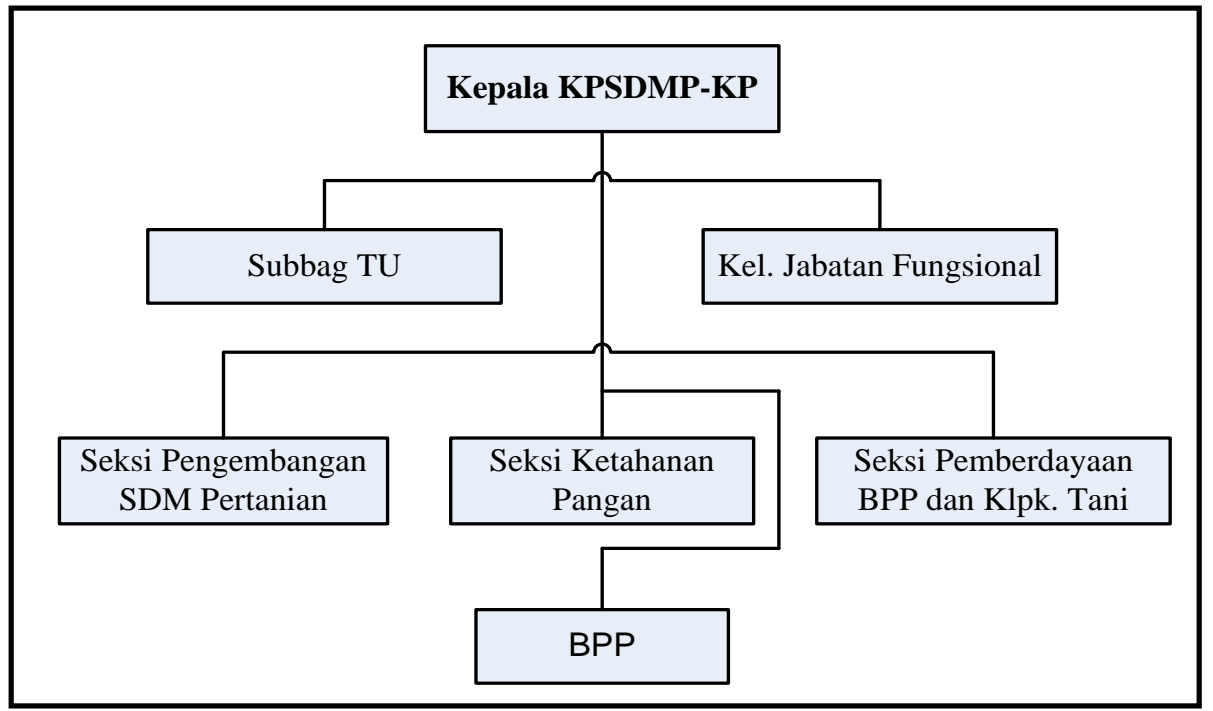

Gambar 1. Struktur Organisasi KPSDMP-KP di Kabupaten Garut

Dari struktur organisasi yang ada di KPSDMP-KP Kabupaten Garut tersebut maka dijabarkan model pendampingan dan pelayanan penyuluhan pertanian yang diberikan sebagaimana terdapat pada Gambar 2. Pada prinsipnya pelayanan penyuluhan yang dilakukan oleh KPSDMP-KP berjenjang mulai tingkat kabupaten, kecamatan dan terakhir desa/kelurahan. Pada tingkat desa terdapat kelompokkelompok tani dengan satu koordinator (ketua kelompok tani) yang berperan sebagai kontak tani.

Kontak tani inilah yang menghubungkan antara penyuluh dan petani jika akan dilakukan suatu pertemuan berkaitan dengan kegiatan bersama. Kontak tani berperan pula melanjutkan informasi yang diperoleh dari penyuluh kepada petani dalam kelompoknya.

Walaupun berjenjang, namun tidak berlaku kaku bahwa penyuluh kabupaten hanya memberikan penyuluhan di tingkat kabupaten. Pelayanan penyuluhan pertanian bersifat fleksibel, apabila penyuluh pertanian di tingkat desa mengalami kesulitan (karena suatu masalah atau karena perkembangan pengetahuan petani yang makin meningkat bahkan melebihi penyuluhnya) maka tidak jarang penyuluh di tingkat kecamatan atau kabupaten turun tangan membantu. 


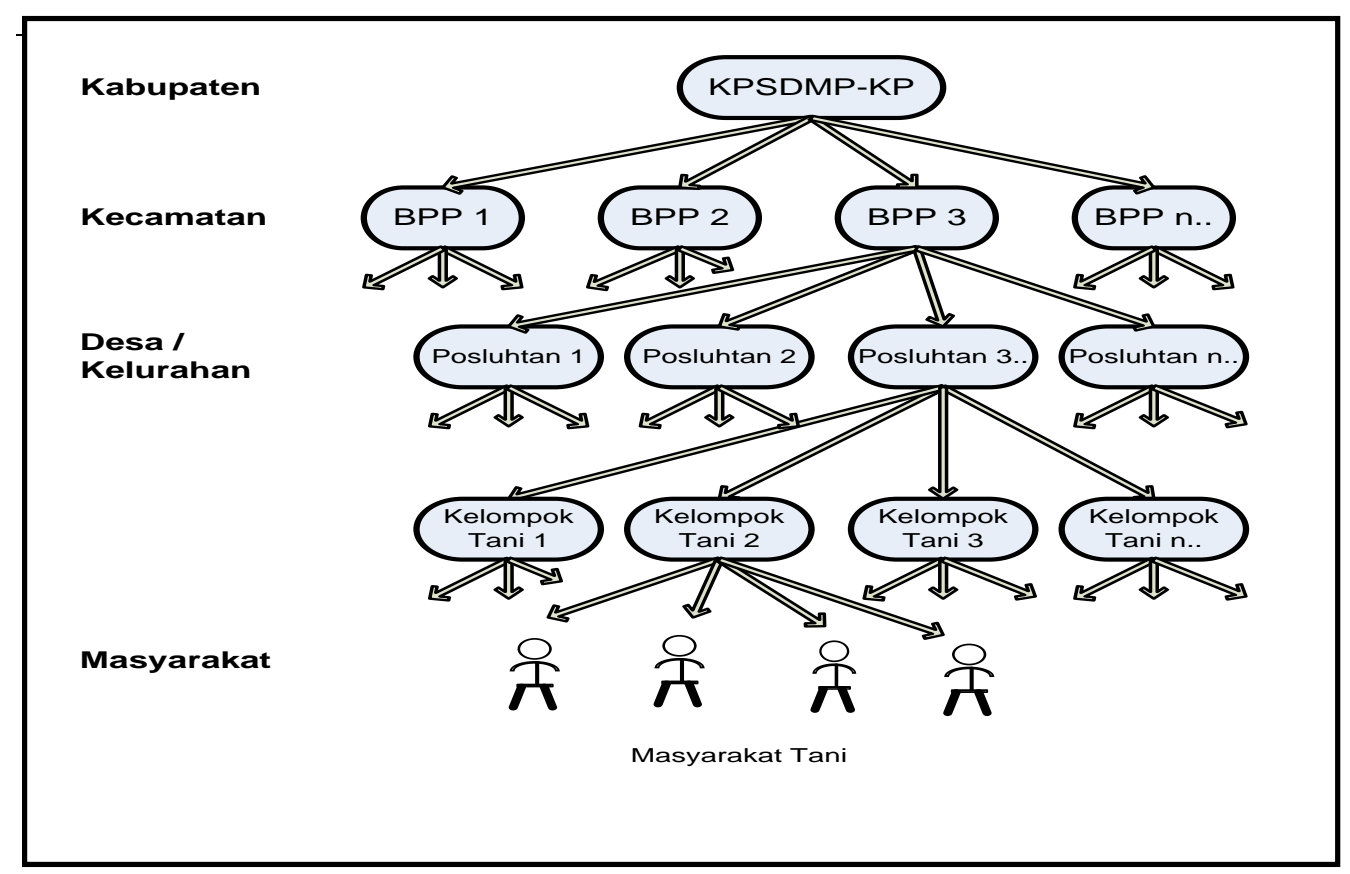

Gambar 2. Model Pelayanan Penyuluhan Pertanian

\section{Penerapan Teori Kualitas Pelayanan oleh Zeithaml, et. al. (1990) di KPSDMP-KP Kabupaten Garut}

Ditinjau dari teori yang dikembangkan oleh Zeithaml, et. al (1990:26) bahwa kualitas pelayanan ditentukan oleh lima dimensi, yaitu tangible, reliability, responsiveness, assurance dan empathy. Dalam variabel kualitas pelayanan tersebut dioperasionalkan kepada 18 butir pertanyaan terdiri dari 4 butir pertanyaan untuk dimensi tangibles, 4 butir pertanyaan untuk dimensi reliability, 3 butir pertanyaan untuk dimensi responsiveness, 3 butir pertanyaan untuk dimensi assurance dan 4 butir untuk dimensi empathy. Tanggapan responden terhadap masing-masing dimensi diuraikan pada penjelasan berikut ini.

\section{Tanggapan Responden Terhadap Dimensi Tangibles}

Tangible diwujudkan pada penampilan fisik dari fasilitas, peralatan, pegawai, sarana komunikasi serta kedisiplinan pegawai pada KPSDMP-KP Kabupaten Garut yang digunakan dalam melaksanakan penyuluhan kepada seluruh petani petani yang ada di Kabupaten Garut. Jawaban dari 100 responden atas kuesioner terhadap masing-masing tanggapan responden mengenai dimensi tangibles dapat terlihat dalam tabel 2 . 
Tabel 2. Tanggapan Responden Terhadap Dimensi Tangibles

\begin{tabular}{|c|c|c|c|c|c|}
\hline \multirow{2}{*}{$\begin{array}{l}\text { Butir } \\
\text { No. }\end{array}$} & \multicolumn{4}{|c|}{ Tingkat persetujuan } & \multirow{2}{*}{$\begin{array}{l}\text { Skor } \\
\text { Total }\end{array}$} \\
\hline & Jawaban & Bobot & $\mathrm{F}$ & $\%$ & \\
\hline \multirow{5}{*}{1} & STS & 1 & 2 & 2 & \multirow{5}{*}{270} \\
\hline & TS & 2 & 41 & 41 & \\
\hline & AST & 3 & 42 & 42 & \\
\hline & S & 4 & 15 & 15 & \\
\hline & SS & 5 & 0 & 0 & \\
\hline \multirow{5}{*}{2} & STS & 1 & 1 & 1 & \multirow{5}{*}{323} \\
\hline & TS & 2 & 6 & 6 & \\
\hline & AST & 3 & 63 & 63 & \\
\hline & $S$ & 4 & 29 & 29 & \\
\hline & SS & 5 & 1 & 1 & \\
\hline \multirow{5}{*}{3} & STS & 1 & 1 & 1 & \multirow{5}{*}{299} \\
\hline & TS & 2 & 19 & 19 & \\
\hline & AST & 3 & 61 & 61 & \\
\hline & $S$ & 4 & 18 & 18 & \\
\hline & SS & 5 & 1 & 1 & \\
\hline \multirow{5}{*}{4} & TS & 2 & 7 & 7 & \multirow{4}{*}{331} \\
\hline & AST & 3 & 55 & 55 & \\
\hline & $\mathrm{S}$ & 4 & 38 & 38 & \\
\hline & SS & 5 & 0 & 0 & \\
\hline & \multicolumn{4}{|c|}{ Kumulatif skor dari empat (4) pertanyaan } & 1223 \\
\hline
\end{tabular}

Sumber : diolah dari jawaban responden atas pertanyaan nomor 1 - 4 .

Selanjutnya dilakukan penghitungan pengkategorian skor berdasarkan interval batasan sehingga diperoleh hasil bahwa skor total dimensi tangibles sebesar 1223 berada pada interval antara 1040 dan 1360 (kategori sedang) sebagaimana digambarkan berikut ini :

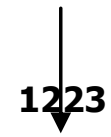

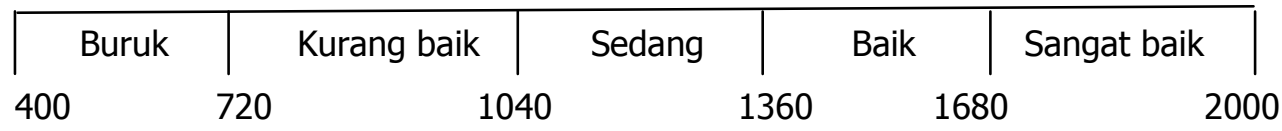

\section{Tanggapan Responden Terhadap Dimensi Reliability}

Reliability merupakan kemampuan penyuluh untuk memberikan pelayanan yang dijanjikan secara cepat dan tepat kepada konsumen yaitu seluruh petani petani yang ada di Kabupaten Garut. Jawaban dari 100 responden atas kuesioner 
terhadap masing-masing tanggapan responden mengenai dimensi reliability dapat terlihat dalam tabel 3.

Tabel 3. Tanggapan Responden Terhadap Dimensi Reliability

\begin{tabular}{|c|c|c|c|c|c|}
\hline \multirow{2}{*}{$\begin{array}{l}\text { Butir } \\
\text { No. }\end{array}$} & \multicolumn{4}{|c|}{ Tingkat persetujuan } & \multirow{2}{*}{$\begin{array}{l}\text { Skor } \\
\text { Total }\end{array}$} \\
\hline & Jawaban & Bobot & $\mathrm{F}$ & $\%$ & \\
\hline \multirow{5}{*}{5} & STS & 1 & 0 & 0 & \multirow{5}{*}{327} \\
\hline & TS & 2 & 8 & 8 & \\
\hline & AST & 3 & 57 & 57 & \\
\hline & $S$ & 4 & 35 & 35 & \\
\hline & SS & 5 & 0 & 0 & \\
\hline \multirow{5}{*}{6} & STS & 1 & 0 & 0 & \multirow{5}{*}{319} \\
\hline & TS & 2 & 12 & 12 & \\
\hline & AST & 3 & 59 & 59 & \\
\hline & $\mathrm{S}$ & 4 & 27 & 27 & \\
\hline & SS & 5 & 2 & 2 & \\
\hline \multirow{4}{*}{7} & TS & 2 & 11 & 11 & \multirow{4}{*}{324} \\
\hline & AST & 3 & 55 & 55 & \\
\hline & $\mathrm{S}$ & 4 & 33 & 33 & \\
\hline & SS & 5 & 1 & 1 & \\
\hline \multirow{4}{*}{8} & TS & 1 & 1 & 1 & \multirow{4}{*}{305} \\
\hline & AST & 2 & 17 & 17 & \\
\hline & $\mathrm{S}$ & 3 & 58 & 58 & \\
\hline & SS & 4 & 24 & 24 & \\
\hline
\end{tabular}

Sumber : diolah dari jawaban responden atas pertanyaan nomor $5-8$.

Kemudian dari penghitungan pengkategorian skor berdasarkan interval batasan diperoleh hasil bahwa skor total dimensi reliability sebesar 1275 berada pada interval antara 1040 dan 1360 (kategori sedang) sebagaimana digambarkan berikut ini :

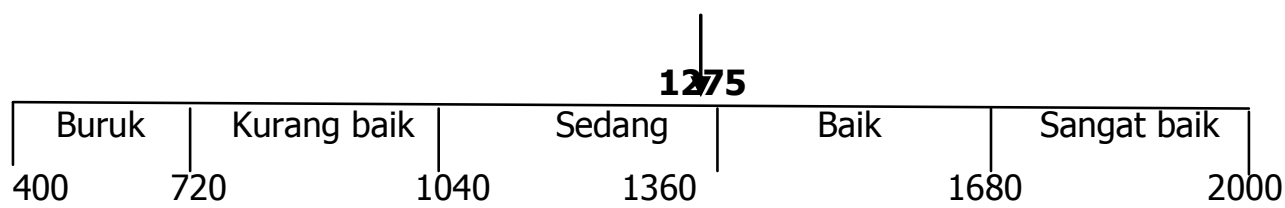




\section{Tanggapan Responden Terhadap Dimensi Responsiveness}

Responsiveness ditunjukkan pada kesediaan dan kesadaran untuk membantu konsumen dengan memberikan pelayanan secara cepat dan tepat. Jawaban dari 100 responden atas kuesioner terhadap masing-masing tanggapan responden mengenai dimensi responsiveness dapat terlihat pada tabel 4.

Tabel 4. Tanggapan Penilaian Responden Terhadap Dimensi Responsinvenes

\begin{tabular}{|c|c|c|c|c|c|}
\hline \multirow{2}{*}{$\begin{array}{l}\text { Butir } \\
\text { No. }\end{array}$} & \multicolumn{4}{|c|}{ Tingkat persetujuan } & \multirow{2}{*}{$\begin{array}{l}\text { Skor } \\
\text { Total }\end{array}$} \\
\hline & Jawaban & Bobot & $\mathrm{F}$ & $\%$ & \\
\hline \multirow{5}{*}{9} & STS & 1 & 1 & 1 & \multirow{5}{*}{324} \\
\hline & TS & 2 & 6 & 6 & \\
\hline & AST & 3 & 62 & 62 & \\
\hline & $\mathrm{S}$ & 4 & 30 & 30 & \\
\hline & SS & 5 & 1 & 1 & \\
\hline \multirow{5}{*}{10} & STS & 1 & 1 & 1 & \multirow{5}{*}{307} \\
\hline & TS & 2 & 16 & 16 & \\
\hline & AST & 3 & 59 & 59 & \\
\hline & $\mathrm{S}$ & 4 & 23 & 23 & \\
\hline & SS & 5 & 1 & 1 & \\
\hline \multirow{4}{*}{11} & TS & 1 & 1 & 1 & \multirow{4}{*}{298} \\
\hline & AST & 2 & 17 & 17 & \\
\hline & $\mathrm{S}$ & 3 & 65 & 65 & \\
\hline & SS & 4 & 17 & 17 & \\
\hline & \multicolumn{4}{|c|}{ Kumulatif skor dari tiga (3) pertanyaan } & 929 \\
\hline
\end{tabular}

Sumber : diolah dari jawaban responden atas pertanyaan nomor $9-11$.

Selanjutnya dilakukan penghitungan pengkategorian skor berdasarkan interval batasan sehingga diperoleh hasil bahwa skor total dimensi responsiveness sebesar 929 berada pada interval antara 780 dan 1020 (kategori sedang) sebagaimana digambarkan berikut ini :

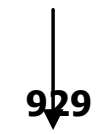

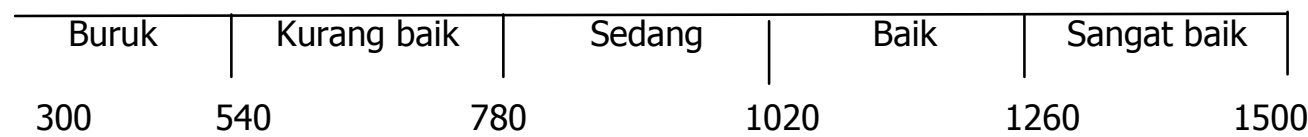




\section{Tanggapan Responden Terhadap Dimensi Assurance}

Assurance merupakan kemampuan dan kesopanan pegawai sehingga menimbulkan kepercayaan dan menjamin penggunaan jasa pelayanan. Jawaban dari 100 responden atas kuesioner terhadap masing-masing tanggapan responden mengenai dimensi assurance dapat terlihat dalam tabel 5 di bawah ini.

Tabel 5. Tanggapan Responden Terhadap Dimensi Assurance

\begin{tabular}{|c|c|c|c|c|c|}
\hline \multirow{2}{*}{$\begin{array}{l}\text { Butir } \\
\text { No. }\end{array}$} & \multicolumn{4}{|c|}{ Tingkat persetujuan } & \multirow{2}{*}{$\begin{array}{l}\text { Skor } \\
\text { Total }\end{array}$} \\
\hline & Jawaban & Bobot & $\mathrm{F}$ & $\%$ & \\
\hline \multirow{4}{*}{12} & TS & 2 & 14 & 14 & \multirow{4}{*}{319} \\
\hline & AST & 3 & 53 & 53 & \\
\hline & $\mathrm{S}$ & 4 & 33 & 33 & \\
\hline & SS & 5 & 0 & 0 & \\
\hline \multirow{4}{*}{13} & TS & 1 & 3 & 3 & \multirow{4}{*}{288} \\
\hline & AST & 2 & 24 & 24 & \\
\hline & $\mathrm{S}$ & 3 & 55 & 55 & \\
\hline & SS & 4 & 18 & 18 & \\
\hline \multirow{6}{*}{14} & STS & 1 & 2 & 2 & \multirow{5}{*}{289} \\
\hline & TS & 2 & 21 & 21 & \\
\hline & AST & 3 & 63 & 63 & \\
\hline & $S$ & 4 & 14 & 14 & \\
\hline & SS & 5 & 0 & 0 & \\
\hline & Kur & skor d & (3) & & 896 \\
\hline
\end{tabular}

Sumber : diolah dari jawaban responden atas pertanyaan nomor $12-14$.

Kemudian dilakukan penghitungan pengkategorian skor berdasarkan interval batasan sehingga diperoleh hasil bahwa skor total dimensi assurance sebesar 896 berada pada interval antara 780 dan 1020 (kategori sedang) sebagaimana digambarkan berikut ini :

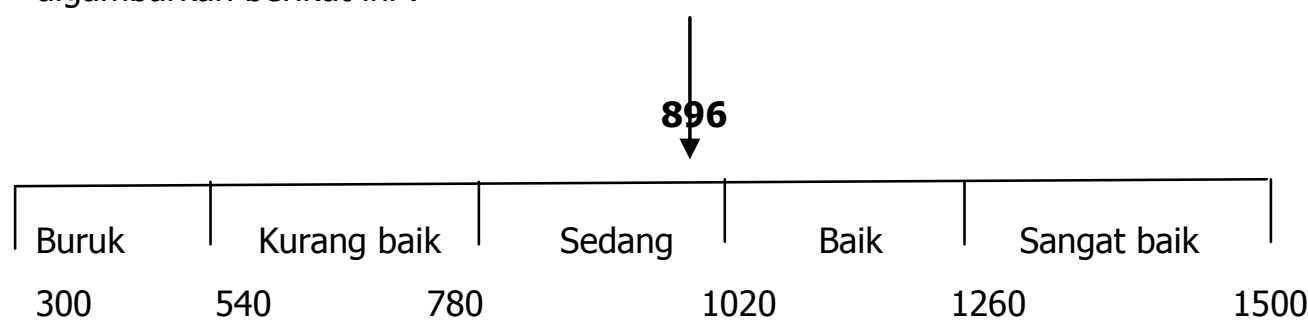

\section{Tanggapan Responden Terhadap Dimensi Empathy}

Emphaty yaitu perhatian yang diberikan kepada pelanggannya. Kesediaan untuk memberikan perhatian, pelayanan melalui pendekatan pribadi, memberikan perlindungan serta berusaha untuk mengetahui keinginan dan kebutuhan petani di 
Kabupaten Garut. Jawaban dari 100 responden atas kuesioner terhadap masingmasing tanggapan responden mengenai dimensi empathy dapat terlihat dalam tabel 6.

Tabel 6. Tanggapan Responden Terhadap Dimensi Empathy

\begin{tabular}{|c|c|c|c|c|c|}
\hline \multirow{2}{*}{$\begin{array}{l}\text { Butir } \\
\text { No. }\end{array}$} & \multicolumn{4}{|c|}{ Tingkat persetujuan } & \multirow[t]{2}{*}{$\begin{array}{l}\text { Skor } \\
\text { Total }\end{array}$} \\
\hline & Jawaban & Bobot & $\mathrm{F}$ & $\%$ & \\
\hline \multirow{5}{*}{15} & STS & 1 & 0 & 0 & \multirow{5}{*}{326} \\
\hline & TS & 2 & 7 & 7 & \\
\hline & AST & 3 & 60 & 60 & \\
\hline & $\mathrm{S}$ & 4 & 33 & 33 & \\
\hline & SS & 5 & 0 & 0 & \\
\hline \multirow{4}{*}{16} & STS & 1 & 1 & 1 & \multirow{4}{*}{317} \\
\hline & TS & 2 & 10 & 10 & \\
\hline & AST & 3 & 60 & 60 & \\
\hline & $\mathrm{S}$ & 4 & 29 & 29 & \\
\hline \multirow{5}{*}{17} & STS & 1 & 0 & 0 & \multirow{5}{*}{355} \\
\hline & TS & 2 & 1 & 1 & \\
\hline & AST & 3 & 43 & 43 & \\
\hline & $\mathrm{S}$ & 4 & 56 & 56 & \\
\hline & SS & 5 & 0 & 0 & \\
\hline \multirow{5}{*}{18} & STS & 1 & 0 & 0 & \multirow{5}{*}{356} \\
\hline & TS & 2 & 2 & 2 & \\
\hline & AST & 3 & 40 & 40 & \\
\hline & $\mathrm{S}$ & 4 & 58 & 58 & \\
\hline & SS & 5 & 0 & 0 & \\
\hline
\end{tabular}

Sumber : diolah dari jawaban responden atas pertanyaan nomor $15-15$.

Kemudian dilakukan penghitungan pengkategorian skor berdasarkan interval batasan sehingga diperoleh hasil bahwa skor total dimensi empathy sebesar 1354 berada pada interval antara 1040 dan 1360 (kategori sedang) sebagaimana digambarkan berikut ini :

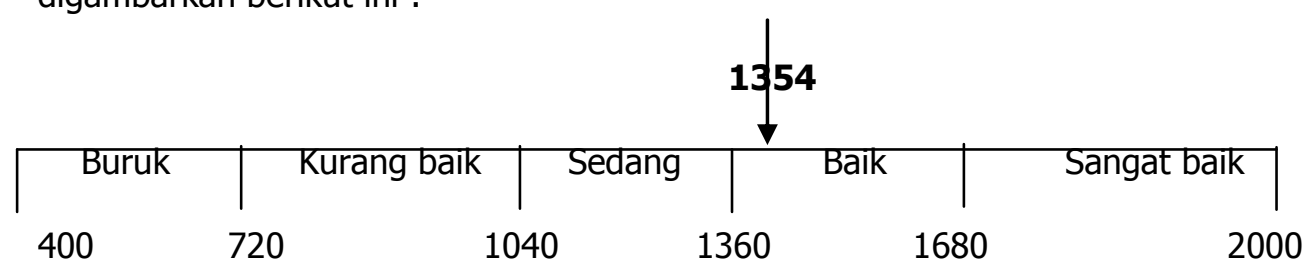


Dari data-data hasil penelitian di atas dapat dijelaskan bahwa Zeithaml, et. al. (1990:26) menekankan di mana kualitas pelayanan ditentukan oleh lima dimensi yaitu tangible, reliability, responsiveness, assurance dan emphaty. Hasil penelitian dan uji statistik terhadap masing-masing dimensi menunjukkan bahwa seluruh dimensi kualitas pelayanan berada pada kategori 'sedang', dengan urutan skor total mulai dari yang tertinggi sampai yang terendah adalah emphaty (1354), reliability (1275), tangible (1223), responsiveness (929) dan terakhir assurance (896).

Assurance menurut Zeithaml, et.al. (1990:26) merupakan knowledge and courtesy of employees and their ability to convey trust and confidence, sehingga dalam penelitian ini penyuluh pertanian harus benar-benar mempunyai kemampuan dan kesopanan sehingga menimbulkan kepercayaan (trust) dan menjamin penggunaan jasa pelayanan. Dalam hal 'pelayanan', kepercayaan pelanggan (petani) adalah hal yang sangat penting. Saat pelanggan sudah percaya bahwa mereka akan mendapatkan apa yang dibutuhkan maka tanpa diminta mereka akan datang dengan sendirinya.

Berkaitan dengan pelayanan penyuluhan pertanian, segala informasi yang berkaitan dengan usaha tani, baik tentang dana usaha, sarana produksi, cara budi daya terbaru yang terjangkau, penanganan pasca panen serta pemasaran adalah yang sangat dibutuhkan oleh petani. Jika itu tidak dapat diberikan oleh penyuluh pertanian maka petani akan cenderung meninggalkan penyuluh yang selama ini menjadi mitranya

Skor total terendah ke dua adalah reliability, yaitu ability to perform the promised service dependably and provide prompt service (Zeithaml, et.al., 1990:26). Penyuluh pertanian harus mempunyai kemampuan untuk memberikan pelayanan yang dijanjikan secara cepat dan tepat kepada konsumen yaitu seluruh petani petani yang ada di Kabupaten Garut. Dimensi reliability pada Kantor Pengembangan SDMP-KP belum optimal di antaranya dilihat dari fakta bahwa :

a Keterbatasan pengetahuan dan ketrampilan penyuluh pertanian baik dalam hal materi penyuluhan maupun cara penyampaian kepada petani menyebabkan kebutuhan petani belum dapat dilayani dengan optimal.

b. Tidak semua penyuluh dapat mengoperasionalisasikan peralatan yang ada sehingga pelaksanaan penyuluhan menjadi belum efektif.

c. Belum semua permasalahan petani dapat segera diberikan solusi yang tepat.

Berikutnya, skor total terendah ke tiga adalah tangible, yaitu appearance of physical facilities, equipment personnel and communication materials. Kualitas pelayanan ditinjau dari dimensi tangible pada Kantor Pengembangan SDMP-KP belum optimal di antaranya karena :

a. Terbatasnya bahkan belum tersedianya sarana dan prasarana pelayanan yang memadai.

b. Sebagian besar penyuluh pertanian yang sudah cukup tua kurang sesuai dengan tugas penyuluh yang memerlukan mobilitas tinggi dan gesit dengan 
penampilan yang menarik perhatian petani sehingga dapat melayani masyarakat petani dengan wilayah kerja yang luas.

c. Belum seluruh penyuluh disiplin dalam melakukan kegiatan-kegiatan penyuluhan yang sudah direncanakan.

Responsiveness (ketanggapan) dan emphaty (empati) adalah dua dimensi yang mendapat penilaian total skor tertinggi dari responden. Hasil ini menunjukkan bahwa penyuluh pertanian pada dasarnya sudah cukup tanggap dan mempunyai empati dalam memberikan pelayanan. Hanya karena jumlah pejabat fungsional (penyuluh) menurun, serta kurang adanya pembinaan pasca otonomi daerah sehingga kualitas pelayanan secara keseluruhan dirasakan kurang oleh petani.

\section{Alternatif Model Pelayanan Penyuluhan Pertanian di KPSDMP-KP Kabupaten Garut}

Berdasarkan hasil penelitian dan pembahasan pada dua sub bab sebelumnya maka penulis memberikan alternatif model sistem informasi berbasis internet sebagai model pelayanan penyuluhan pertanian di KPSDMP-KP Kabupaten Garut sebagaimana dijelaskan pada Gambar 3 berikut ini.

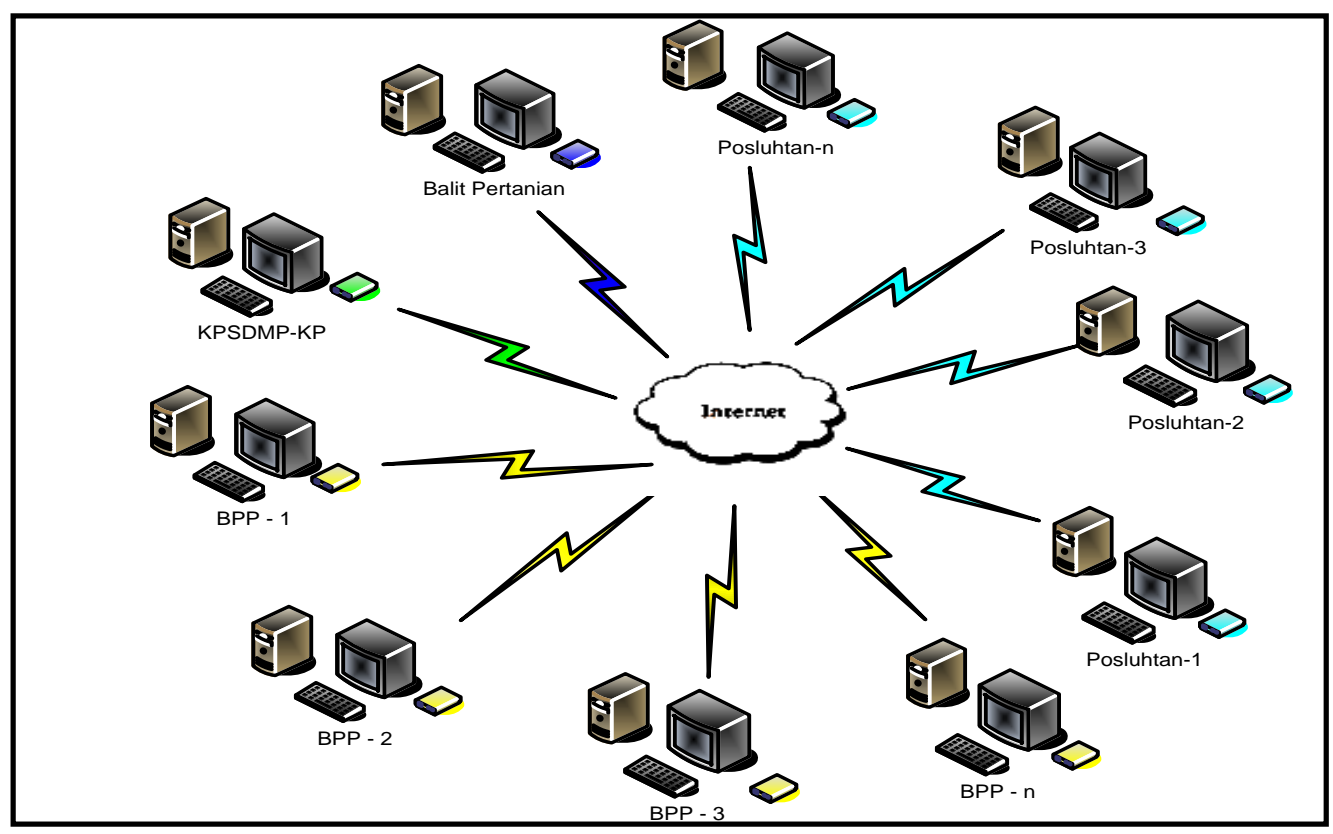

Gambar 3. Skema Jaringan Informasi sampai Tingkat Desa

Sistem informasi ini menurut hemat penulis penting dikembangkan karena 1) Wilayah kerja KPSDMP-KP meliputi BPP dan Posluhtan yang secara geografis tersebar di seluruh wilayah Kabupaten Garut, sehingga komunikasi yang didukung 
oleh sistem informasi yang baik antara penyuluh yang ada di kabupaten, kecamatan dan desa sangat diperlukan untuk memberikan pelayanan yang terbaik kepada petani. 2) Inovasi-inovasi baru di bidang pertanian dari Balai Penelitian dan Pengembangan Pertanian akan lebih cepat diakses oleh KPSDMP-KP. 3) Sistem Informasi penting pula untuk menambah pengetahuan terbaru berkaitan dengan segala informasi yang berkaitan dengan usaha tani (agribisnis) mulai dari hulu sampai hilir.

Skema pada Gambar 3 di atas dapat diaplikasikan secara bertahap tergantung kemampuan biaya dan kesiapan (keterampilan) dari operator yang menjalankan. Hasil penelitian diketahui pula bahwa di tingkat kabupaten (KPSDMP-KP) dan sebagian besar kecamatan (BPP) sudah memiliki computer, sehingga tinggal menambah alat yang dapat digunakan untuk mengakses jaringan internet. Alangkah baiknya jika pada saat sistem informasi berbasis internet ini diaplikasikan disertai dengan pelatihan sampai operator (dari pegawai KPSDMP-KP) dapat dilepas untuk menjalankan sistem tersebut. Sehingga ketergantungan kepada pihak penyedia jasa layanan dapat dikurangi bahkan dihilangkan.

Adapun mekanisme model pelayanan penyuluhan pertanian pada Gambar 3 dapat dilakukan dengan alur sebagai berikut :

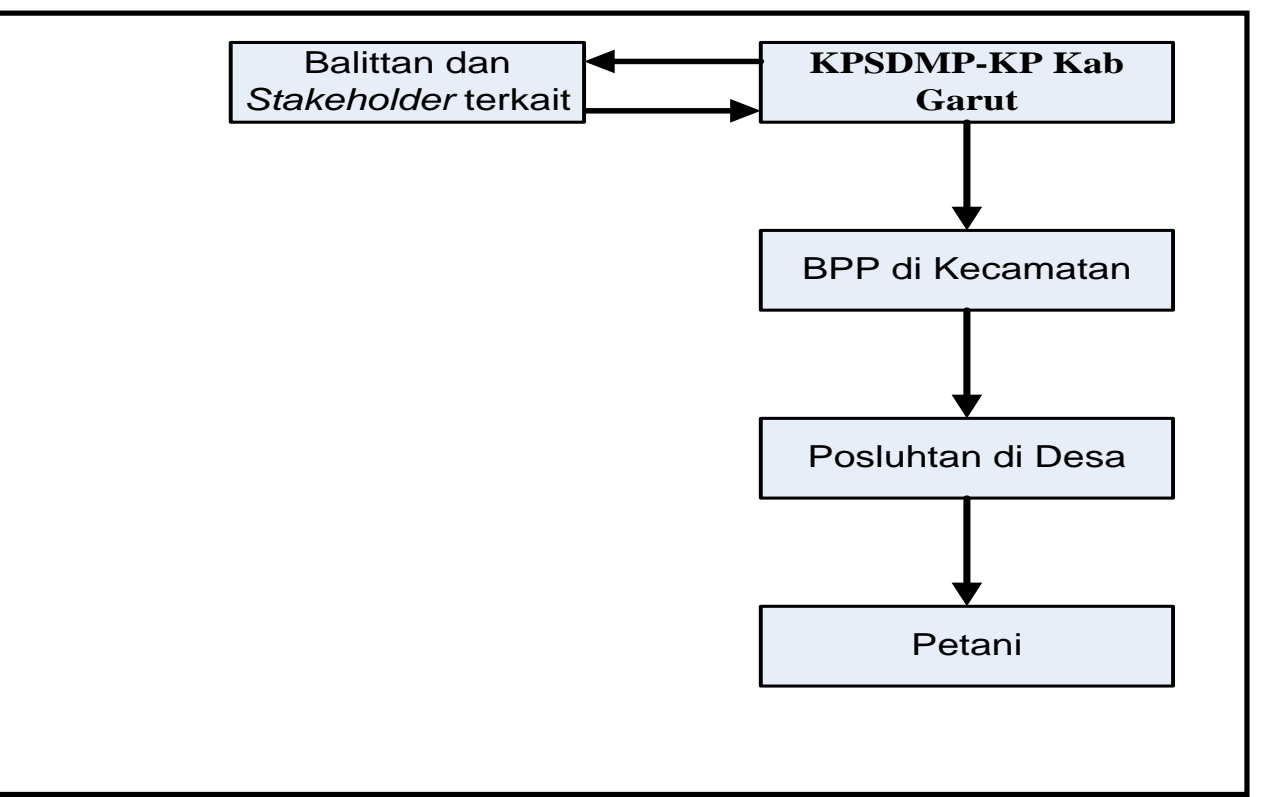

Gambar 4. Mekanisme Model Pelayanan Penyuluhan Pertanian

Saat aplikasi sistem informasi berbasis internet sudah diberlakukan, maka sebenarnya siapapun yang terkait dalam sistem pelayanan penyuluhan pertanian tersebut maupun pihak-pihak lainnya dapat dengan mudah mengakses informasiinformasi yang dibutuhkan. Hanya agar informasi dapat tepat sasaran maka 
'moderator' dihandle oleh petugas di KPSDMP-KP Kabupaten Garut. Petugas tersebut ditugaskan secara khusus untuk mengatur ke mana informasi dikirimkan dan memilah informasi mana yang boleh dan tidak boleh disebarluaskan dengan persetujuan pejabat KPSDMP-KP terkait.

Program tahap awal yang penting yaitu penyampaian informasi melalui penggunaan mailist (mailing list), dalam hal ini bermanfaat untuk meningkatkan pengetahuan penyuluh yang saat ini benar-benar haus akan perkembangan/inovasi-inovasi terbaru di bidang pertanian. Dengan mailist ini diharapkan penyuluh, lembaga-lembaga penelitian di bidang pertanian, pemerintah kabupaten, petani dan pihak swasta yang berkaitan dengan bidang pertanian dapat saling berinteraksi dan memberikan manfaat yang lebih besar pada masingmasing pihak. Khususnya bagi KPSDMP-KP diharapkan dapat memberikan pelayanan yang lebih cepat dan lebih baik lagi bagi petani di Kabupaten Garut. Jika kondisi ini tercapai maka akan mengembalikan kepercayaan (trust) dari pelanggan (petani) yang sejak otonomi daerah sedikit demi sedikit menurun.

\section{SIMPULAN}

Beberapa simpulan dari penelitian ini adalah sebagai berikut :

1. Pada penelitian ini diperoleh temuan penting bahwa setelah otonomi daerah justru jumlah, kualitas dan kompetensi penyuluh pertanian menjadi menurun sehingga kualitas pelayanan yang diberikan kepada petani menjadi menurun pula.

2. Dalam penerapan teori Zeithaml, et. al (1990:26) dimensi assurance mendapatkan penilaian paling rendah dari responden. Hasil ini memberikan petunjuk bahwa perubahan kualitas pelayanan sebaiknya dimulai dari dimensi assurance ini sehingga kepercayaan petani terhadap pelayanan yang diberikan oleh KPSDMP-KP Kabupaten Garut dapat meningkat kembali.

3. Model pengembangan yang dapat diberikan yaitu dengan memberikan fasilitas sistem informasi disertai pelatihan yang intensif untuk meningkatkan kinerja penyuluh pertanian sehingga dapat meningkatkan kualitas pelayanan yang diberikan.

\section{DAFTAR PUSTAKA}

Gaspersz. 1997. Manajemen Kualitas, Penerapan Konsep-konsep Kualitas Dalam Bisnis Total. Terjemahan Sudarsono. Jakarta : PT Gramedia.

Lovelock and Wirtz. 1994. Services Marketing : People, Technology, Strategy. United State of America : Pearson Prentice Hall.

Lenvine, C. H. et al. 1990. Public Administration; Chalenges, Choices, Consequences. Illinois: Scott Foreman.

Mahmudi. 2005. Manajemen Kinerja Sektor Publik. Yogyakarta : UPP AMP YKPN. 
Sugiyanti, 1999. Strategi Pelayanan Prima. Jakarta : Lembaga Administrasi Negara RI.

Singarimbun., dkk., 1995. Metode Penelitian Survai. Jakarta : LP3ES.

Sugiyono. 2004. Metode Penelitian Administrasi. Bandung : Alfabeta.

Umar, H. 2004. Metode Riset Ilmu Administrasi; Ilmu Administrasi Negara, Pembangunan dan Niaga. Jakarta : Gramedia Pustaka Utama

Zeithaml, V. A., A. Parasuraman and L. Berry. 1990. Delivering Quality Service. New York : The Free Press. 